\title{
FINANCIAL PERFORMANCE OF BANKS IN PAKISTAN: A COMPARATIVE ANALYSIS OF PUBLIC AND PRIVATE SECTORS
}

\author{
FAISAL $^{1}$, MUHAMMAD TARIQ $^{2}$ AND DR. FARZAND ALI JAN ${ }^{3}$ \\ ${ }^{1}$ Department of Management Sciences, AWKUM. \\ faisal@awkum.edu.pk \\ ${ }^{2}$ Department of Management Sciences, AWKUM. \\ ${ }^{2}$ tariqraeeszada@yahoo.com \\ ${ }^{3}$ Department of Management Sciences, Hazara University, Mansehra. \\ ${ }^{3}$ Sevdam90@ hotmail.com
}

\begin{abstract}
This study is an attempt to analyze and compare the financial performance of MCB Bank Ltd and National Bank of Pakistan by applying common size analysis and ratio analysis of financial statement of banks. The secondary data was utilized in analysis of balance sheet, profit and loss statements and other accounting information for the financial year 2005-09. Both banks are very important financial institution and are providing different facilities to the customers. The banks also give advances to the other industries, companies and other deficit economic units. The results obtained shows considerable improvement in financial performance by banks in both public and private sectors. The financial strengths of banks depend on the liquidity, profitability and the ability of banks to pay its debt. All these three have showed improvements but there are some of the financial indicators in both which still needs improvement like current ratio, return on equity and operating profit of both banks. The findings of the analysis of financial statements of both banks show that MCB had utilized their assets more efficiently and effectively as compared to NBP. The return on equity ratio of MCB Bank is much better then National bank of Pakistan for the FY-2005-09 which banks ability to produce earning \& therefore is an excellent indicator both of viability \& capability of banks management. Both banks must invest more in liquid assets like marketable security and market treasury bills to boost the trust of the depositors on banks. Both banks should also decrease their debt level in order to utilize the funds at the right time and at the right level to enhance their net profits.
\end{abstract}

Keywords: Common size Analysis, Ratio Analysis, Vertical Analysis, Current ratio.

INTRODUCTION: Banks are the most important financial institutions which play a vital role throughout the world's economic system. According to the Chambers English Dictionary the term "Bank" means a "Bench" or an institution or an exchange company. Caircross (1170) defines bank as a financial intermediary and a dealer to create credits. Bank can also be defined as the institution for collection of funds from the community and credit to its customers by way of advances against goods or securities, or by discounting bills for the useful purpose. In other words bank is custodian of wealth and people have faith in it to invest their funds wisely. Furthermore the bank is also responsible for its stock holders being a profit seeking business and not a community charity which attempts to maximize the wealth of its shareholders. A bank is therefore a person or a corporation which deals in credits i.e. accepts deposits from the public (Surplus economic units) and advances loans to the External parties (deficit economic units). 


\subsection{Origin of Banking}

The origin of the banking is traceable in the ancient Assyrian Babylonian and Athencies but the founders of the banking are to be considered to be the Bank of Venice (1171), the bank of Geneva (1320) and the bank of Amsterdam (1609) (Hussain, 2008)

The system of banking in arose out of the fact that people who possess surplus coins deposited for safe keeping with person in whom they had confidence and to be paid after a period of tie when they might need them. Holders of the coins soon found that it was profitable to lend the money provided loans were repaid before the date when money would be needed. Probably, banks as they were, really given signed paper for their deposits as evidence of the deposit money. Babylonians were so impressed of the temple banking that they drew out a code of ethics for this system.

\subsection{Banking in Pakistan}

Prior to pre-partition entire banking sector was dominated by the Hindus. This created a great financial vacuum after shifting of their business to India.

Our great leader, the founder of Pakistan Quaid-e-Azam Muhammad Ali Jinnah, at that critical period, accepted this challenge with faith and confidence on Al-Mighty Allah, and to continue with his mission, invited some of his loyal friends and Muslim business community to share his responsibilities. These friends in response showed great ad Patriotism and offered their services morally and financially as were required for the economic development of the newly formed Muslim State.

\subsection{Private Banking in Pakistan}

Habib Bank Ltd., which was functioning in Bombay, shifted to Pakistan in the year 1947 and extended its network throughout the country with its head office at Karachi. The Australasian Bank Limited has already been in operation in Pakistan since 1942. In 1974 nationalization of banking was introduced in which MCB was the first bank which was nationalized but the bank didn't show a remarkable performance and later on in 1991 it was again privatized.

\subsection{Public Sector Banking in Pakistan}

The record shows that from 1961 onward the government established the following banks to provide services to the citizens for the proper utilization of the country's resources in the field of industrial, agricultural, housing, Expert financing, Technical Assistance, saving bank schemes and project financing. Currently public sector banks in Pakistan are National Bank of Pakistan, Zarai Taraqiati Bank Ltd, Small \& Medium Enterprise Bank, Industrial Development Bank and First Women Bank Ltd. In public sector banking this study is confined to National Bank of Pakistan which was established vide NBP Ordinance No. XIX of November 9, 1949 and is listed on all the stock exchanges of Pakistan. The bank is engage in providing commercial banking and related services in Pakistan.

\subsection{Justification and Back ground of the Study}

Each and every stake holders analyze the current financial position of an organization so as to search out the profitable new financial vistas for future. For this purpose the analysis of financial performance can be done by using the ratio analysis and proper interpretation of each and every ratio.

It is believed that findings of the study will help to improve the financial management and performance of the both of the banks that are operating i.e., National Bank of Pakistan and MCB Bank LTD.

The successful completion of this study will be more helpful in understanding the comparison of performance of both the public \& private sectors. This research is also helpful in providing a literature review in future for the current study.

\subsection{Objectives of the Study}

This study is designed to analyze the comparison of performance of public and private sectors in Pakistan. The more specific objectives of the study are:

- $\quad$ to evaluate the operating income of both banks.

- $\quad$ to work out financial analysis e.g., Ratio Analysis to facilitate business management decision by stakeholders.

- $\quad$ to forward recommendations \& various suggestions for improvement of financial management of both the banks. 
2. REVIEW OF LITERATURE: Kitching, et al. (1982) large organizations and particularly organizations with the complex structure of branch banking require time to change. The author does not suggest that there are any clear answers to the strategic planning problems facing branch banking. Today's advanced technology provides new tools to respond to change and progress. To do this accurate assessment of market segments, an effective internal management structure, efficient management and a level and quality of staff to use the new technology are required. This, in turn, will demand new recruitment and training methods.

Hartvigsen, et al. (1992) studied that financial analysis is considered to be a knowledge-intensive task, involving knowledge from several areas. Nowadays, banking is exploring knowledge-based systems to improve operational efficiency and customer relations while currently reducing costs. Financial analysis is one of the promising areas for these kinds of applications. This author examines the limitations of the utilization of knowledge-based systems within financial analysis (i.e., the lack of a theoretical framework for such analysis). Furthermore, we show how some of these limitations have been met in the design and implementation of the KABAL system, which is a knowledge-based system for financial analysis. (Kabal is the Norwegian word for patience)

Salmi and Martikainen, et al. (1994) conducted a critical review of the theoretical and empirical basis of four central areas of financial ratio analysis. The research areas reviewed were the functional form of the financial ratios, distributional characteristics of financial ratios, classification of financial ratios, and the estimation of the internal rate of return from financial statements. The study found that it is typical of financial ratio analysis research that there are several unexpectedly distinct lines with research traditions of their own. A common feature of all the areas of financial ratio analysis research seems to be that while significant regularities can be observed, they are not necessarily stable across the different ratios, industries, and time periods. This leaves much space for the development of a more robust theoretical basis and for further empirical research.

Ruthenberg and Elias (1996), studied the creation of a single European banking market is expected to increase cross-border competition, reduce existing differences in cost inefficiencies, and arbitrage away price-cost margins between EC members and other European banks. In this paper, we estimated cost economies and operating efficiencies in this market and test the structure-performance theorem empirically. Using 1989-1990 data for individual EC and non-EC banks, we found a U-shaped average cost curve coupled with differences in efficiencies between banks, suggesting that there are potential gains from reallocation of resources among them. The results, with respect to potential changes in price-cost margins, show that changes in market structure will have a positive effect on interest margins only in banking markets characterized by relatively low concentration and low entry barriers.

Nabi, et al. (1997) studied the Pakistan's ongoing policy reform aims to strengthen the competitive foundations of the economy and make it more outward-oriented. This study reviews the recent trade performance and progress regarding tariff reform. Management of the exchange rate as a principle tool of trade policy is further elaborated and quiet clearly explained.

Kuljis and Robert (1998) found that the banking sector provides an interesting focus for the problems of information provision to support decision making as it is undergoing a period of rapid intensification of competition and fundamental change where new products and services are both agents and consequences of change. This study introduces the banking sector in order to provide background information and an insight into the complexities of the business area. The authors further discuss decision making and the associated role of information and communication technologies. This will lead into a review of information that is required to support decision making and the difficulties that arise in gathering and managing this information.

Boyd, et al. (2001) studied that a growing theoretical literature describes mechanisms whereby even predictable increases in the rate of inflation interfere with the ability of the financial sector to allocate resources effectively. They empirically assess these predictions. The evidence indicates that there is a significant, and economically important, negative relationship between inflation and both banking sector development and equity market activity. Further, the relationship is nonlinear. As inflation rises, the marginal impact of inflation on banking lending activity and stock market development diminishes rapidly. Moreover, they also find evidence of thresholds. For economies with inflation rates exceeding 15 percent, there is a discrete drop in financial sector performance. Finally, while the data indicate that more inflation is not matched by greater nominal equity returns in low-inflation countries, nominal stock returns move essentially one-for-one with marginal increases in inflation in high-inflation economies.

Porta, et al. (2002) used data of government owned banks from 92 countries around the world, finds that government ownership of banks is high in countries which are characterized by "low levels of per capita income. Underdeveloped financial systems, interventionist and inefficient governments and poor protection 
of property rights". The study further finds evidence that government ownership of banks is associated with slower subsequent financial development, lower economic growth and especially lower growth of productivity.

Emel, et al. (2003) analyze how to manage credit risk, commercial banks use various scoring methodologies to evaluate the financial performance of client firms. The quantitative analyses were used in the financial performance modules of state-of-the-art credit scoring methodologies. This innovation should help lending officers in branch levels filter out the poor risk applicants. The Data Envelopment Analysis-based methodology was applied to current data for 82 industrial/manufacturing firms comprising the credit portfolio of one of Turkey's largest commercial banks. Using financial ratios, the DEA synthesizes a firm's overall performance into a single financial efficiency score - the "credibility score". Results were validated by various supporting (regression and discriminant) analyses and, most importantly, by expert judgments based on data or on current knowledge of the firms.

Sapienza, et al. (2004) provides an information on individual loan contracts to study the effects of government ownership on bank lending behavior. State-owned banks charge lower interest rates than do privately owned banks to similar or identical firms, even if firms are able to borrow more from privately owned banks. State-owned banks mostly favor large firms and firms located in depressed areas. The lending behavior of state-owned banks is affected by the electoral results of the party affiliated with the bank: the stronger the political party in the area where the firm is borrowing, the lower the interest rates charged.

Boubakri, et al. (2005) examined the post privatization performance of 81 banks from 22 developing countries. Our results suggest that: (i) on average, banks chosen for privatization have a lower economic efficiency, and a lower solvency than banks kept under government ownership. (ii) In the post privatization period, profitability increases but, depending on the type of owner, efficiency, risk exposure and capitalization may worsen or improve. However, (iii) Over time, privatization yields significant improvements in economic efficiency and credit risk exposure. (iv) We also find that newly privatized banks that are controlled by local industrial groups become more exposed to credit risk and interest rate risk after privatization.

Berger, et al. (2005) analyzes the static, selection, and dynamic effects of domestic, foreign, and state ownership on bank performance. The author argued that it was important to include indicators of all the relevant governance effects in the same model. "No robustness" checks (which purposely exclude some indicators) support this argument. Used data from Argentina in the 1990s, strongest and most robust results concern state ownership. State-owned banks have poor long-term performance (static effect), those undergoing privatization had particularly poor performance beforehand (selection effect), and these banks dramatically improved following privatization (dynamic effect), although much of the measured improvement is likely due to placing nonperforming loans into residual entities, leaving "good" privatized banks.

Barros, et al. (2007) used a dataset of 7635 observations on 1384 commercial banks operating in the EU between 1993 and 2001; they utilized a mixed logic model to identify factors that explain the probability of a bank being a best [worst] performer. The empirical evidence confirms the importance of country-level characteristics (location and legal tradition), and firm- level features (bank ownership, balance sheet structure and size), Specifically, smaller sized banks with higher loan-intensity, and foreign banks from countries upholding common law traditions have a higher probability of best performance.

Ali and Ansari, et al. (2007) assessed the impact of Financial Sector reforms on the soundness of banks operating in Pakistan over the last two decades. They study found that financial sector reforms introduced in late 1980s made a significant impact on the soundness of banks. There has been a consolidation and merger of banks, capital adequacy ratios look much stronger, and asset has been strengthened by the induction of professionals at the top and second tiers. An important achievement in the last decade has been the transformation of a largely state owned and weak banking system into healthier, primarily privately owned system. This has been facilitated by restricting of major banks ongoing corporate governance and credit culture. The study suggested the continuation of banking sector reforms. Though major efforts have been undertaken by the government to update and improve the legislative frame work, there remains a need to repeal, amend and update laws.

Rehman and Ahmad, et al. (2008) analyzed the major determinants of a bank section by a customer in the banking industry of Pakistan. It is based in a survey of 358 customers of private, privatized and nationalized banks located in the city of Lahore (Pakistan). The findings of the study reveal that the most important variables influencing customers' choice are customer services, convenience, on live banking facilities and over all bank environments. The study aims to bridge the existing gap in local banking literature through identifying the important bank selection determinants and conclude with some policy implications which are 
expected to have an important impact on the marketing efforts of Pakistani banks.

Shaikh, et al. (2008) constructed financial statement analysis within international context. The study found the usefulness of case financial statement and its advantages is a notion of financial data can be meaningfully interpreted when it is evaluated relative to comparable quantity. The case provides a forum for you that analyst should make appropriate adjustment before undertaking any comparative financial statement analysis and past is not always an unqualified guide to the future for accounting decision making. Certain comparative analyses (leases) cannot be done since all companies do not provide full information in the absence of analytical accounting adjustment.

Iqbal and Raza, et al. (2009) analyzed how European banks have developed from 2003 to 2007 based on three questions. Five European banks served as case studies to analyze their growth through qualitative and quantitative methods using a descriptive rectangle model based on financial statement framework. It was found that the banks developed unsystematically through acquisitions, joint ventures and joint investments in different countries and did not follow a systematic pattern to expand their business operations. Expansion of core banking business was less significant. It was also found that the financial statements; especially financial assets were interpreted in a way that is difficult to understand for external users. All five Banks achieved strong growth from 2003-2006, but 2007 was problematic in some of their divisions due to real estate crisis which started in the US, and then spread on to financial institutions all over the world.

Ravichandran, et al. (2009) analyzed the financial statement of Sundaram Clayton, Ltd. is taken up the office at Chennai for analyzing the stability of the organization in terms of analyzing and computing the various ratio analysis from the balance sheet and profit and Loss Accounts of the organization for 5 consecutive years form 2002 to 2006. The study predicted the financial state of the organization, its strength and weakness and its stages where it has to improve and giving the overall position of the organization for the management for decision making so that its resources are used most effectively and efficiently. This study not only help the management, it also gives a clear -view to the owners, share holders, creditors and investors.

Shahriar and Tehranian, et al. (2010) examines government ownership and government involvement in a country's banking system affect bank performance from 1989 through 2004. The study uncovers an interesting pattern of changing performance differences between state-owned and privately-owned banks around the Asian financial crisis. They found that state-owned banks operated less profitably, held less core capital, and had greater credit risk than privately-owned banks prior to 2001, and the performance differences are more significant in those countries with greater government involvement and political corruption in the banking system. In addition, from 1997 to 2000, the 4-year period after the beginning of the Asian financial crisis, the deterioration in the cash flow returns, core capital, and credit quality of stateowned banks was significantly greater than that of privately-owned banks, especially for the countries that were hardest hit by the Asian crisis. However, state-owned banks closed the gap with privately-owned banks on cash flow returns, core capital, and nonperforming loans in the post-crisis period of 2001-2004.

3. RESEARCH METHODOLOGY: Investors, creditors, and other business people rely on accounting information to make intelligent, informed decisions. The balance sheet, the profit and loss account and the statement of cash flows provide a large part of the information that is used for making decision. Various techniques are used to analyze and interpret financial statement data. This study includes scope of the study, Data and Sources of Data, followed by Analytical Framework.

\subsection{Population:}

Many banks are currently operating in public and private sector of Pakistan. Private sector banks include MCB Bank Ltd, United Bank Ltd, Askari Commercial Bank, Allied Bank Ltd, and Bank Al-Falah.

Public sector banks include State Bank of Pakistan, National Bank of Pakistan, Zarai Taraqiati Bank Ltd, Small \& Medium Enterprise Bank, Industrial Development Bank and First Women Bank Ltd is considered to be population for this study.

\subsection{Sample Study:}

The main objective of this study is to evaluate and compare the financial performance of banks in public and private sectors of Pakistan. For this purpose National Bank of Pakistan (the public sector) and MCB Bank Ltd (private sector) is purposively selected. Therefore, the study is limited to the financial information for the period 2005 to 2009 .

\subsection{Data Collection and Sources of Data:}


Business firms publish financial statements at least annually, and most large companies also issue them quarterly. Normally, annual statements are attested to be certified by public. Accountants and the careful analyst read the accountants' opinion to determine the reliability of the given data. These statements, which are available to any interested party, are generally more useful than annual reports because they furnish a greater amount of detail. Even more details can be found in prospectuses submitted to the Security Exchange Commission of Pakistan (SEC) by certain companies issuing large amounts of new securities tools and techniques to evaluate the financial efficiency and performance of the financial institutions to facilitate the informed decision making process by all stakeholders. The following sections explain and present the formulation of these financial tools and techniques of analysis.

\subsection{Data Analysis:}

The data analysis of financial statement has been carried out by using ratio analysis. The ratio analysis is also used to better understand the company's performance by properly interpreting it. Without a proper interpretation a ratio is meaningless by itself.

\subsection{Ratio Analysis}

Though Ratio analysis we can understand better the company's performance. However a ratio is meaningless by itself. Comparing the ratio to last year's ratio and understanding the reasons for the change is important. This understanding will gives us insight in to banks performance. The following ratios are calculated and possible interpretation for the change in the ratio will be explained.

\subsubsection{Liquidity Ratios}

Liquidity ratio measures the ability of the firm to meet its short-term obligations. These ratios are important the cause failure to pay such obligations can lead to bankruptcy. Bankers use liquidity ratios to see whether to extend short -term credit to a firm. Higher the liquidity ratio, the more able the firm is to its short -term obligations.

Liquidity ratio compares current assets to current liabilities and serves as the liquid reserve available to satisfy contingencies and uncertainties. The ratio indicates the short term solvency of a business and in determining if a firm can pay its current liabilities when due. This Ratio is explained along with formula as follow:

\section{a) Current Ratio}

The current ratio compares all the current assets (cash and other assets that can be easily converted to cash) to all the current liabilities (liabilities that must be paid with cash). Current ratio fluctuates from industry to industry. A current ratio significantly higher than the industry average could indicate the existence of redundant assets. Conversely, a current ratio significantly lowers than the industry average could indicate a lack of liquidity.

Current Ratio

\section{$=\quad$ Current Assets}

\section{Current Liabilities}

3.5.3.2 Profitability Ratios: Profitability ratio measures how the firm's returns compare to its sales. Profitability relates to a company's ability to earn a satisfactory income. A company's profitability is closely linked to its liquidity because earnings ultimately produce cash flow. The Profitability Ratios is further classified into five types of Ratios. They are described along with formula as below:

\section{a) Net Profit Margin}

The net profit margin measures how much profit out of each sales is left after all expenses are subtracted, that is all taxes expenses are subtracted.

\section{Net Profit Margin $\quad=\quad$ Profit after Taxes $x 100$}

b) Operating Profit Margin

The operating profit margin is calculated by dividing earnings before interest and taxes by sales revenue.

\section{Operating Profit Margin $=\quad$ Earnings before interest and taxes $x 100$}

\section{Sales}

\section{c) Return on Assets}

The return on assets (ROA) ratio indicates how much income generated by each or assets .It shows whether the business is investing in its assets effectively. The return on assets is calculated by dividing net income by the total assets. 
d) Profit per Employee Computation:

This ratio measures the firm's net profit after tax per average number of employees that are working in an organization. This ratio measures the exact level of profit per employee upon which the management of an organization can decide whether to downsize or right size the number of employees.

\section{Profit per Employee Computation = \\ Net profit (earnings) after tax}

e) Assets per Employee Computation:

Average number of employees

This ratio measures the firm's profit of total assets per average number of employees that are working in an organization. This ratio measures the exact level of profit of total assets per employee upon which the management of an organization can decide whether to invest in current or fixed assets.

Assets per Employee Computation = $\quad \underline{\text { Total Assets }}$

f) Return on Equity

Average number of employees

The return on Equity ratio measures the income earned on the shareholders investment in the business. It is calculated by dividing net income by stockholders equity.

\section{Return on Equity = $\quad$ Net Income $x 100$

$$
\text { Total Equity }
$$

g) Total Assets Turnover

This ratio measures how efficiently a firm is using its assets. A company having high asset utilization ratio suggests that its assets help promote its sale revenue. Measures the activity of the assets and the ability of the business to generate sales through the use of the assets.

Total Assets Turnover $=\quad \underline{\text { Sales }} \times 100$

\section{Total Assets}

\subsubsection{Debt Ratio}

The financial analysis use debt ratios to assess the relative size of a firm's debt load and the firm's ability payoff the debts. The debts ratios are used to evaluate the safety of long-term creditors: For these ratios of analysis the higher the number, the greater the amount of safety.

a) Debt-Assets Ratio: This ratio measures the percentage of the firm's assets that are financed with debts. Provides information about the company's ability to absorb asset reductions arising from losses without jeopardizing the interest of creditors.
Debt-Assets Ratio
$=$
Total Debts $x 100$

\section{Total Assets}
b) Debt-

Equity Ratio: The Debt-Equity ratio is the percentage of debt relative to the amount of equity. Indicates how well creditors are protected in case of the company's insolvency.
Debt-Equity Ratio
$=\quad$ Total debts $x 100$
Total Equity

\section{RESULTS AND DISCUSSIONS}

\section{FINANCIAL STATEMENT RATIOS FOR MCB AND NATIONAL BANK OF PAKISTAN, FOR THE YEAR ENDED Dec. 31, 2005 TO Dec 31, 2009.}

\subsection{Ratio Analysis.}

Ratios are used to measure the comparative performance of any organization with the industry. Due to the non-availability of financial information of other entities of the banking sector, the ratio based on the financial figure for five years, of MCB and National Bank of Pakistan has been computed.

\subsubsection{Liquidity Ratios \\ a) Current Ratio}
Current Ratio
$=$
Current Assets

\section{Current Liabilities}

Current Ratio: (MCB)

TABLE NO. 4.1

\begin{tabular}{|l|l|l|l|l|}
\hline S. No & Years & Current Assets & Current Liabilities & Results \\
\hline $\mathbf{1}$ & $\mathbf{2 0 0 5}$ & 215456463 & 8536674 & 25.24 \\
\hline $\mathbf{2}$ & $\mathbf{2 0 0 6}$ & 258363948 & 7089679 & 36.44 \\
\hline
\end{tabular}




\begin{tabular}{|l|l|l|l|l|}
\hline $\mathbf{3}$ & $\mathbf{2 0 0 7}$ & 263503372 & 10479058 & 25.14 \\
\hline $\mathbf{4}$ & $\mathbf{2 0 0 8}$ & 310284821 & 10551468 & 29.41 \\
\hline $\mathbf{5}$ & $\mathbf{2 0 0 9}$ & 301034271 & 8201090 & 36.71 \\
\hline
\end{tabular}

Current Ratio: (NBP)

TABLE NO. 4.2

\begin{tabular}{|l|l|l|l|l|}
\hline S. No & Years & Current Assets & Current Liabilities & Results \\
\hline $\mathbf{1}$ & $\mathbf{2 0 0 5}$ & 387338007 & 1757785 & 220.35 \\
\hline $\mathbf{2}$ & $\mathbf{2 0 0 6}$ & 458210044 & 10618898 & 43.15 \\
\hline $\mathbf{3}$ & $\mathbf{2 0 0 7}$ & 494487781 & 7095456 & 69.71 \\
\hline $\mathbf{4}$ & $\mathbf{2 0 0 8}$ & 574963262 & 10244335 & 56.12 \\
\hline $\mathbf{5}$ & $\mathbf{2 0 0 9}$ & 639064039 & 10663798 & 59.93 \\
\hline
\end{tabular}

This ratio indicates the financial position of the firm in which there are sufficient liquid assets to meet the short term debts. This ratio indicates the short term solvency of business when due. A higher rate of this ratio means that the firm is financially strong enough to pay all its current debt moreover or in other words the firm is in strong position and is having higher value in the market. In the above computation MCB is having lower current ratio the national bank of Pakistan because of the difference in the level of assets national bank is holding which is a government bank having a government assets and treasury. Both banks are having fluctuation in the current ratio for the FY-2005-09.

\subsubsection{Profitability Ratios}

a) Net Profit Margin

Pre / after-tax Profit. (MCB)

TABLE NO. 4.3

\begin{tabular}{|l|l|l|l|l|l|l|l|}
\hline S.No & Year & $\begin{array}{l}\text { Pre-Tax } \\
\text { Profit }\end{array}$ & Sales & Percentage & $\begin{array}{l}\text { After-Tax } \\
\text { Profit }\end{array}$ & Sales & Percentage \\
\hline $\mathbf{1}$ & $\mathbf{2 0 0 5}$ & $13,018,487$ & $23,169,303$ & $56.19 \%$ & $8,922,415$ & $23,169,303$ & $38.3 \%$ \\
\hline $\mathbf{2}$ & $\mathbf{2 0 0 6}$ & $18,500,670$ & $30,769,477$ & $60.13 \%$ & $12,142,398$ & $30,769,477$ & $39.46 \%$ \\
\hline $\mathbf{3}$ & $\mathbf{2 0 0 7}$ & $21,308,035$ & $37,797,886$ & $56.37 \%$ & $15,265,562$ & $37,797,886$ & $40.39 \%$ \\
\hline $\mathbf{4}$ & $\mathbf{2 0 0 8}$ & $21,867,566$ & $45,835,264$ & $47.71 \%$ & 15374600 & $45,835,264$ & $33.53 \%$ \\
\hline $\mathbf{5}$ & $\mathbf{2 0 0 9}$ & 23154945 & $57,258,892$ & $40.44 \%$ & 15495297 & $57,258,892$ & $27.06 \%$ \\
\hline
\end{tabular}

Pre / After-tax Profit (NBP)

TABLE NO. 4.4

\begin{tabular}{|l|l|l|l|l|l|l|l|}
\hline S.No & Year & $\begin{array}{l}\text { Pre-Tax } \\
\text { Profit }\end{array}$ & Sales & Percentage & $\begin{array}{l}\text { After-Tax } \\
\text { Profit }\end{array}$ & Sales & Percentage \\
\hline $\mathbf{1}$ & $\mathbf{2 0 0 5}$ & $19,056,028$ & $43,058,360$ & $44.26 \%$ & $12,709,444$ & $43,058,360$ & $29.52 \%$ \\
\hline $\mathbf{2}$ & $\mathbf{2 0 0 6}$ & $26,310,577$ & $56,263,826$ & $46.76 \%$ & $17,022,346$ & $56,263,826$ & $30.25 \%$ \\
\hline $\mathbf{3}$ & $\mathbf{2 0 0 7}$ & $28,060,501$ & $64,114,326$ & $43.77 \%$ & $19,033,773$ & $64,114,326$ & $29.69 \%$ \\
\hline $\mathbf{4}$ & $\mathbf{2 0 0 8}$ & $23,000,998$ & $77,358,660$ & $29.73 \%$ & $15,458,590$ & $77,358,660$ & $19.98 \%$ \\
\hline $\mathbf{5}$ & $\mathbf{2 0 0 9}$ & $22,300,173$ & $96,973,054$ & $23 \%$ & $18,211,846$ & $96,973,054$ & $18.78 \%$ \\
\hline
\end{tabular}

From the year 2005 to 2009 , MCB's pre-tax profit decrease from $56.19 \%$ to $40.44 \%$ due to significant natural disaster and financial crunch all over the world. As compared with NBP pre tax profit has decreased from $44.26 \%$ to $23.00 \%$. By observing and comparing Pre tax ratios of both the banks the affects of global recession ,natural disasters, frequent changes in the Government policies has affected more MCB as compared to the National bank. Similarly profit after tax for the FY-2005-2009 both banks have showed fluctuation during this period. In the end of FY-2009 both banks earned lowest ever profit during the period.

Pre / after -tax return on equity : (MCB)

TABLE NO. 4.5

\begin{tabular}{|l|l|l|l|l|l|l|l|}
\hline S.No & Year & $\begin{array}{l}\text { Pre-Tax } \\
\text { Profit }\end{array}$ & Total Equity & $\begin{array}{l}\text { Pre-tax } \\
\text { Return } \\
\text { Equity }\end{array}$ & $\begin{array}{l}\text { After-Tax } \\
\text { Profit }\end{array}$ & $\begin{array}{l}\text { Total } \\
\text { Equity }\end{array}$ & $\begin{array}{l}\text { Return on } \\
\text { equity After } \\
\text { Tax }\end{array}$ \\
\hline $\mathbf{1}$ & $\mathbf{2 0 0 5}$ & $13,018,487$ & $23,307,763$ & $55.85 \%$ & $8,922,415$ & $23,307,763$ & $38.28 \%$ \\
\hline $\mathbf{2}$ & $\mathbf{2 0 0 6}$ & $18,500,670$ & $40,844,314$ & $45.30 \%$ & $12,142,398$ & $40,844,314$ & $29.73 \%$ \\
\hline $\mathbf{3}$ & $\mathbf{2 0 0 7}$ & $21,308,035$ & $55,119,675$ & $38.66 \%$ & $15,265,562$ & $55,119,675$ & $27.70 \%$ \\
\hline
\end{tabular}




\begin{tabular}{|c|c|c|c|c|c|c|c|c|c|}
\hline 4 & \multirow[t]{2}{*}{$\frac{2008}{2009}$} & $21,867,566$ & $58,436,054$ & $\frac{37.42 \%}{3200 \%}$ & \multirow{2}{*}{\multicolumn{2}{|c|}{$\begin{array}{l}15374600 \\
15495297\end{array}$}} & \multirow{2}{*}{\multicolumn{2}{|c|}{$\begin{array}{l}58,436,054 \\
69740013\end{array}$}} & $\frac{26.31 \%}{2220 \%}$ \\
\hline 5 & & & 69740013 & $33.20 \%$ & & & & & $22.22 \%$ \\
\hline \multicolumn{10}{|c|}{$\begin{array}{l}\text { Pre / After -tax Return on equity :( NBP) } \\
\text { TABLE NO. 4.6 }\end{array}$} \\
\hline S.No & $\begin{array}{l}\text { Ye } \\
\text { ar }\end{array}$ & $\begin{array}{l}\text { Pre-Tax } \\
\text { Profit }\end{array}$ & $\begin{array}{l}\text { Total } \\
\text { Equity }\end{array}$ & $\begin{array}{l}\text { Pre-tax } \\
\text { Return } \\
\text { on } \\
\text { Equity }\end{array}$ & $\begin{array}{l}\text { After-Tax } \\
\text { Profit }\end{array}$ & & & $\begin{array}{l}\text { Retur } \\
\text { Tax }\end{array}$ & n equity After \\
\hline 1 & $\begin{array}{l}200 \\
5\end{array}$ & $\begin{array}{l}19,056,02 \\
8\end{array}$ & $46,245,732$ & $41.21 \%$ & $12,709,444$ & & 5,732 & $27.48 \%$ & \\
\hline 2 & $\begin{array}{l}200 \\
6\end{array}$ & $\begin{array}{l}26,310,57 \\
7\end{array}$ & $74,340,712$ & $35.39 \%$ & $17,022,346$ & & 0,712 & $22.90 \%$ & \\
\hline 3 & $\begin{array}{l}200 \\
7\end{array}$ & $\begin{array}{l}28,060,50 \\
1\end{array}$ & $81,954,118$ & $34.24 \%$ & $19,033,773$ & & 4,118 & 23.229 & \\
\hline 4 & $\begin{array}{l}200 \\
8\end{array}$ & $\begin{array}{l}23,000,99 \\
8\end{array}$ & $\begin{array}{l}116,337,65 \\
4\end{array}$ & $19.77 \%$ & $15,458,590$ & & 37,65 & $13.29 \%$ & \\
\hline 5 & $\begin{array}{l}200 \\
9\end{array}$ & $\begin{array}{l}22,300,17 \\
3\end{array}$ & $\begin{array}{l}102,459,21 \\
8\end{array}$ & $21.76 \%$ & $18,211,846$ & & 59,21 & 17.779 & \\
\hline
\end{tabular}

This ratio is a measure of banks ability to produce earning $\&$ therefore is an excellent indicator both of viability \& capability of banks management. A high return on equity reflects that banks acceptance of strong investment opportunities \& effective expense management. For the FY-2005 to FY-2009 of MCB pre-tax return on equity was $55.85 \%$ to $33.20 \%$ and similarly of NBP pre tax return was $41.21 \%$ to $21.76 \%$. In the FY-2005-09 decreased because of an overall increase in expenses by the banks. Similarly for the FY-2005 to FY-2009 of MCB After-tax return on equity was $38.28 \%$ to $22.20 \%$ and similarly of NBP After tax return was $27.48 \%$ to $17.77 \%$. In the FY-2005-09 fluctuation in the ratio occurs because of an overall increase in expenses by the banks.

\section{Return on Assets:}

3): Return on assets (Pre / after -tax profit) :( MCB)

Pre-tax returns on assets ratio shows that how effectively total net assets have been employed by MCB. (In \%)

TABLE NO. 4.7

\begin{tabular}{|l|l|l|l|l|l|l|l|}
\hline $\begin{array}{l}\text { S.N } \\
\mathbf{0}\end{array}$ & $\begin{array}{l}\text { Yea } \\
\mathbf{r}\end{array}$ & $\begin{array}{l}\text { Pre-Tax } \\
\text { Profit }\end{array}$ & Total Assets & $\begin{array}{l}\text { Pre-Tax } \\
\text { Return } \\
\text { on an } \\
\text { Assets }\end{array}$ & $\begin{array}{l}\text { After-Tax } \\
\text { Profit }\end{array}$ & $\begin{array}{l}\text { Total } \\
\text { Assets }\end{array}$ & $\begin{array}{l}\text { Return on } \\
\text { Assets } \\
\text { After Tax }\end{array}$ \\
\hline $\mathbf{1}$ & $\begin{array}{l}\mathbf{2 0 0} \\
\mathbf{5}\end{array}$ & $\begin{array}{l}13,018,48 \\
7\end{array}$ & $298,776,797$ & $4.36 \%$ & $8,922,415$ & $\begin{array}{l}298,776,79 \\
7\end{array}$ & $2.99 \%$ \\
\hline $\mathbf{2}$ & $\begin{array}{l}\mathbf{2 0 0} \\
\mathbf{6}\end{array}$ & $\begin{array}{l}18,500,67 \\
0\end{array}$ & $342,108,243$ & $5.41 \%$ & $12,142,398$ & $\begin{array}{l}342,108,24 \\
3\end{array}$ & $3.55 \%$ \\
\hline $\mathbf{3}$ & $\begin{array}{l}\mathbf{2 0 0} \\
\mathbf{7}\end{array}$ & $\begin{array}{l}21,308,03 \\
5\end{array}$ & $410,485,517$ & $5.19 \%$ & $15,265,562$ & $\begin{array}{l}410,485,51 \\
7\end{array}$ & $3.72 \%$ \\
\hline $\mathbf{4}$ & $\begin{array}{l}\mathbf{2 0 0} \\
\mathbf{8}\end{array}$ & $\begin{array}{l}21,867,56 \\
6\end{array}$ & $443,615,904$ & $4.93 \%$ & $15,374,600$ & $\begin{array}{l}443,615,90 \\
4\end{array}$ & $3.47 \%$ \\
\hline $\mathbf{5}$ & $\begin{array}{l}\mathbf{2 0 0} \\
\mathbf{9}\end{array}$ & $\begin{array}{l}23,154,94 \\
5\end{array}$ & $509,223,727$ & $4.55 \%$ & $15,495,297$ & $\begin{array}{l}509,223,72 \\
7\end{array}$ & $3.04 \%$ \\
\hline
\end{tabular}

Return on assets (Pre / after -tax profit): (NBP)

TABLE NO. 4.8

\begin{tabular}{|l|l|l|l|l|l|l|l|}
\hline $\begin{array}{l}\text { S. } \\
\text { No }\end{array}$ & $\begin{array}{l}\text { Yea } \\
\text { r }\end{array}$ & $\begin{array}{l}\text { Pre-Tax } \\
\text { Profit }\end{array}$ & Total Assets & $\begin{array}{l}\text { Pre-Tax } \\
\text { Return on } \\
\text { an Assets }\end{array}$ & $\begin{array}{l}\text { After-Tax } \\
\text { Profit }\end{array}$ & $\begin{array}{l}\text { Total } \\
\text { Assets }\end{array}$ & $\begin{array}{l}\text { Return on } \\
\text { Assets } \\
\text { After Tax }\end{array}$ \\
\hline $\mathbf{1}$ & $\begin{array}{l}\mathbf{2 0 0} \\
\mathbf{5}\end{array}$ & $\begin{array}{l}19,056,02 \\
8\end{array}$ & $577,719,114$ & $3.30 \%$ & $12,709,444$ & $\begin{array}{l}577,719,11 \\
4\end{array}$ & $2.20 \%$ \\
\hline $\mathbf{2}$ & $\begin{array}{l}\mathbf{2 0 0} \\
\mathbf{6}\end{array}$ & $\begin{array}{l}26,310,57 \\
7\end{array}$ & $635,132,711$ & $4.14 \%$ & $17,022,346$ & $\begin{array}{l}635,132,71 \\
1\end{array}$ & $2.68 \%$ \\
\hline
\end{tabular}




\begin{tabular}{|c|l|l|l|l|l|l|l|}
\hline $\mathbf{3}$ & $\mathbf{2 0 0}$ & $28,060,50$ & $762,193,593$ & $3.67 \%$ & $19,033,773$ & $\begin{array}{l}762,193,59 \\
3\end{array}$ & $2.49 \%$ \\
\hline $\mathbf{7}$ & $\begin{array}{l}\mathbf{2 0 0} \\
\mathbf{8}\end{array}$ & $\begin{array}{l}23,000,99 \\
8\end{array}$ & $817,758,326$ & $2.81 \%$ & $15,458,590$ & $\begin{array}{l}817,758,32 \\
6\end{array}$ & $1.89 \%$ \\
\hline $\mathbf{5}$ & $\begin{array}{l}\mathbf{2 0 0} \\
\mathbf{9}\end{array}$ & $\begin{array}{l}22,300,17 \\
3\end{array}$ & $944,232,762$ & $2.36 \%$ & $18,211,846$ & $\begin{array}{l}944,232,76 \\
2\end{array}$ & $1.93 \%$ \\
\hline
\end{tabular}

This ratio is used in calculating whether management has earned a reasonable return with the assets under its control. Pre-tax return on assets in the FY-2005-09 of MCB was $4.36 \%$. to $4.55 \%$ due to increase in assets. Similarly NBP Pre-tax return on assets in the FY-2005-09 of NBP was 3.30\%. to $2.36 \%$ also increase due to increase in assets. On the other hands both banks after tax profits on assets for the FY-2005-09 had showed fluctuation.

\section{Net Profit Margin \\ Net Profit Margin: (MCB)}

\section{TABLE NO. 4.9}

\begin{tabular}{|l|l|l|l|l|}
\hline S. No & Years & Profit After Taxes & Sales & Percentages \\
\hline $\mathbf{1}$ & $\mathbf{2 0 0 5}$ & $8,922,415$ & $23,169,303$ & $38.51 \%$ \\
\hline $\mathbf{2}$ & $\mathbf{2 0 0 6}$ & $12,142,398$ & $30,769,477$ & $39.46 \%$ \\
\hline $\mathbf{3}$ & $\mathbf{2 0 0 7}$ & $15,265,562$ & $37,797,886$ & $40.39 \%$ \\
\hline $\mathbf{4}$ & $\mathbf{2 0 0 8}$ & 15374600 & $45,835,264$ & $33.54 \%$ \\
\hline $\mathbf{5}$ & $\mathbf{2 0 0 9}$ & 15495297 & $57,258,892$ & $27.06 \%$ \\
\hline
\end{tabular}

Net Profit Margin: (NBP)

\section{TABLE NO. 4.10}

This

\begin{tabular}{|l|l|l|l|l|}
\hline S. No & Years & Profit After Taxes & Sales & Percentages \\
\hline $\mathbf{1}$ & $\mathbf{2 0 0 5}$ & $12,709,444$ & $43,058,360$ & $29.52 \%$ \\
\hline $\mathbf{2}$ & $\mathbf{2 0 0 6}$ & $17,022,346$ & $56,263,826$ & $30.25 \%$ \\
\hline $\mathbf{3}$ & $\mathbf{2 0 0 7}$ & $19,033,773$ & $64,114,326$ & $29.69 \%$ \\
\hline $\mathbf{4}$ & $\mathbf{2 0 0 8}$ & $15,458,590$ & $77,358,660$ & $19.98 \%$ \\
\hline $\mathbf{5}$ & $\mathbf{2 0 0 9}$ & $18,211,846$ & $96,973,054$ & $18.78 \%$ \\
\hline
\end{tabular}

provides management of banks with data that can be compared with the actual gross profit margin. Investor and share holder take particular note of the net profit margin as indicators of earnings available for dividends and reinvestments. This ratio also measures profitability with respect to income generated. Net Profit margin of MCB for the FY-2005-09 has showed fluctuation due to different level of income. Net Profit margin of NBP for the FY-2005-09 has decreased due to decrease in the level of income of bank.

E. Operating Profit Margin

Operating Profit Margin: (MCB)

\section{TABLE NO. 4.11}

\begin{tabular}{|l|l|l|l|l|}
\hline S.No & $\begin{array}{l}\text { Yea } \\
\text { rs }\end{array}$ & Earnings before interest and taxes & Sales & Percentages \\
\hline $\mathbf{1}$ & $\mathbf{2 0 0 5}$ & $15,799,955$ & $23,169,303$ & $68.19 \%$ \\
\hline $\mathbf{2}$ & $\mathbf{2 0 0 6}$ & $23,026,029$ & $30,769,477$ & $74.83 \%$ \\
\hline $\mathbf{3}$ & $\mathbf{2 0 0 7}$ & $29,173,568$ & $37,797,886$ & $77.18 \%$ \\
\hline $\mathbf{4}$ & $\mathbf{2 0 0 8}$ & $33,428,306$ & $45,835,264$ & $72.93 \%$ \\
\hline $\mathbf{5}$ & $\mathbf{2 0 0 9}$ & $38,996,408$ & $57,258,892$ & $68.11 \%$ \\
\hline
\end{tabular}

Operating Profit Margin: (NBP)

\begin{tabular}{|l|l|l|l|l|}
\hline S. No & Years & Earnings before interest and taxes & Sales & $\begin{array}{l}\text { Perce } \\
\text { ntages }\end{array}$ \\
\hline $\mathbf{1}$ & $\mathbf{2 0 0 5}$ & $29,377,796$ & $43,058,360$ & $\begin{array}{l}68.23 \\
\%\end{array}$ \\
\hline
\end{tabular}




\begin{tabular}{|l|l|l|l|l|}
\hline $\mathbf{2}$ & $\mathbf{2 0 0 6}$ & $40,257,795$ & $56,263,826$ & $\begin{array}{l}71.55 \\
\%\end{array}$ \\
\hline $\mathbf{3}$ & $\mathbf{2 0 0 7}$ & $45,000,512$ & $64,114,326$ & $\begin{array}{l}70.19 \\
\%\end{array}$ \\
\hline $\mathbf{4}$ & $\mathbf{2 0 0 8}$ & $46,885,766$ & $77,358,660$ & $\begin{array}{l}60.61 \\
\%\end{array}$ \\
\hline $\mathbf{5}$ & $\mathbf{2 0 0 9}$ & $61,789,822$ & $96,973,054$ & $\begin{array}{l}63.72 \\
\%\end{array}$ \\
\hline
\end{tabular}

\section{TABLE NO. 4.12}

For the FY-2005-09, MCB's operating profit decrease from $68.19 \%$ to $68.11 \%$ which is a very negligible decrease and shows the stability of overall policies and operations of the banks. As compared with NBP operating profit has decreased from $68.23 \%$ to $63.72 \%$. By observing and comparing operating profits of both the banks the national bank of Pakistan has showed almost $4.51 \%$ as compared with the MCB of only $0.08 \%$ which is a very slight decrease as compared to NBP. This ratio showed that operating profit is more stable and consistent in MCB rather than the NBP.

F. Profit per Employee Computation:

Profit per Employee Computation: (MCB)

TABLE NO. 4.13

\begin{tabular}{|l|l|l|l|l|}
\hline \hline S. No & Years & Net Profit( Earnings) After Taxes & $\begin{array}{l}\text { Average number of } \\
\text { Employees }\end{array}$ & $\begin{array}{l}\text { Profit per } \\
\text { Employee }\end{array}$ \\
\hline $\mathbf{1}$ & $\mathbf{2 0 0 5}$ & $8,922,415$ & 9377 & 951.52 \\
\hline $\mathbf{2}$ & $\mathbf{2 0 0 6}$ & $12,142,398$ & 9011 & 1347.51 \\
\hline $\mathbf{3}$ & $\mathbf{2 0 0 7}$ & $15,265,562$ & 9721 & 1570.37 \\
\hline $\mathbf{4}$ & $\mathbf{2 0 0 8}$ & $15,374,600$ & 10160 & 1513.25 \\
\hline $\mathbf{5}$ & $\mathbf{2 0 0 9}$ & 15495297 & 9397 & 1648.96 \\
\hline
\end{tabular}

Profit per Employee Computation: (NBP)

TABLE NO. 4.14

\begin{tabular}{|l|l|l|l|l|}
\hline \hline S. No & Years & $\begin{array}{l}\text { Net Profit( Earnings) After } \\
\text { Taxes }\end{array}$ & $\begin{array}{l}\text { Average number of } \\
\text { Employees }\end{array}$ & $\begin{array}{l}\text { Profit per } \\
\text { Employee }\end{array}$ \\
\hline $\mathbf{1}$ & $\mathbf{2 0 0 5}$ & $12,709,444$ & 13824 & 919.37 \\
\hline $\mathbf{2}$ & $\mathbf{2 0 0 6}$ & $17,022,346$ & 14019 & 1214.24 \\
\hline $\mathbf{3}$ & $\mathbf{2 0 0 7}$ & $19,033,773$ & 14079 & 1352.35 \\
\hline $\mathbf{4}$ & $\mathbf{2 0 0 8}$ & $15,458,590$ & 15204 & 1017.54 \\
\hline $\mathbf{5}$ & $\mathbf{2 0 0 9}$ & $18,211,846$ & 16248 & 1121.67 \\
\hline
\end{tabular}

This ratio indicates that the banks past performance an industry averages form the basis of comparison. It is a measure of efficiency in terms of staff level and net profits generated. From the definition of above ratio which shows a clear picture that MCB bank generates more profit per employee as compare to National Bank.

G. Assets per Employee Computation:

Assets per Employee Computation: (MCB)

TABLE NO. 4.15

\begin{tabular}{|l|l|l|l|l|}
\hline S. No & Years & Total Assets & Average number of Employees & Results \\
\hline $\mathbf{1}$ & $\mathbf{2 0 0 5}$ & $298,776,797$ & 9377 & 31862.73 \\
\hline $\mathbf{2}$ & $\mathbf{2 0 0 6}$ & $342,108,243$ & 9011 & 37965.62 \\
\hline $\mathbf{3}$ & $\mathbf{2 0 0 7}$ & $410,485,517$ & 9721 & 42226.68 \\
\hline $\mathbf{4}$ & $\mathbf{2 0 0 8}$ & $443,615,904$ & 10160 & 43662.98 \\
\hline $\mathbf{5}$ & $\mathbf{2 0 0 9}$ & $509,223,727$ & 9397 & 54190.03 \\
\hline
\end{tabular}

Assets per Employee Computation: (NBP)

TABLE NO. 4.16

\begin{tabular}{|l|l|l|l|l|}
\hline S. No & Years & Total Assets & Average number of Employees & Results \\
\hline $\mathbf{1}$ & $\mathbf{2 0 0 5}$ & $577,719,114$ & 13824 & 41791.02 \\
\hline $\mathbf{2}$ & $\mathbf{2 0 0 6}$ & $635,132,711$ & 14019 & 45305.14 \\
\hline $\mathbf{3}$ & $\mathbf{2 0 0 7}$ & $762,193,593$ & 14079 & 54136.91 \\
\hline $\mathbf{4}$ & $\mathbf{2 0 0 8}$ & $817,758,326$ & 15204 & 53785.74 \\
\hline $\mathbf{5}$ & $\mathbf{2 0 0 9}$ & $944,232,762$ & 16248 & 58113.78 \\
\hline
\end{tabular}


This ratio shows the results of the computation are used as comparisons with the banking industry averages and the banks past performance. It's a measure of efficiency in terms of staff levels and funds invested in assets. From the above explanation it can be observed as the investment of each employee of NBP is greater then MCB Bank. From the FY-2005-09 in NBP each employee investment increases from Rupees 41791.02 (in thousands) to Rupees 58113.78(in thousands) as compared with the MCB for the FY-2005-09 Rupees 31862.73(in thousands) to Rupees 54190.03 (in thousands).

\section{H. Total Assets Turnover \\ Asset Turnover: (MCB)}

TABLE NO. 4.17

\begin{tabular}{|l|l|l|l|l|}
\hline S. No & Years & Sales & Total Assets & Percentage \\
\hline $\mathbf{1}$ & $\mathbf{2 0 0 5}$ & $23,169,303$ & $298,776,797$ & $7.75 \%$ \\
\hline $\mathbf{2}$ & $\mathbf{2 0 0 6}$ & $30,769,477$ & $342,108,243$ & $8.99 \%$ \\
\hline $\mathbf{3}$ & $\mathbf{2 0 0 7}$ & $37,797,886$ & $410,485,517$ & $9.21 \%$ \\
\hline $\mathbf{4}$ & $\mathbf{2 0 0 8}$ & $45,835,264$ & $443,615,904$ & $10.33 \%$ \\
\hline $\mathbf{5}$ & $\mathbf{2 0 0 9}$ & $57,258,892$ & $509,223,727$ & $11.24 \%$ \\
\hline
\end{tabular}

Asset Turnover: (NBP)

TABLE NO. 4.18

\begin{tabular}{|l|l|l|l|l|}
\hline S. No & Years & Sales & Total Assets & Percentage \\
\hline $\mathbf{1}$ & $\mathbf{2 0 0 5}$ & $43,058,360$ & $577,719,114$ & $7.45 \%$ \\
\hline $\mathbf{2}$ & $\mathbf{2 0 0 6}$ & $56,263,826$ & $635,132,711$ & $8.86 \%$ \\
\hline $\mathbf{3}$ & $\mathbf{2 0 0 7}$ & $64,114,326$ & $762,193,593$ & $8.41 \%$ \\
\hline $\mathbf{4}$ & $\mathbf{2 0 0 8}$ & $77,358,660$ & $817,758,326$ & $9.46 \%$ \\
\hline $\mathbf{5}$ & $\mathbf{2 0 0 9}$ & $96,973,054$ & $944,232,762$ & $10.27 \%$ \\
\hline
\end{tabular}

This ratio provides management with a level of assets that they can compare with industry averages or the banks past performance. If the banks can generate increased revenues with the same level of assets this would indicates a more efficient use of investments funds as can be observed from the above ratio of MCB for a FY-2005-09 the bank utilized assets in profitable way as increased had occurred in the FY-2009.

Similarly the NBP assets turn over ratio for a FY-2005-09 has improved as the bank utilized assets in profitable way as increased had occurred in the FY-2009 and the investors had full trust in the policies of managements of both banks.

\subsubsection{Debt Ratio}

A. Debt-Assets Ratio

8) Total Debt to Total Assets : (MCB)

\section{TABLE NO. 4.18}

\begin{tabular}{|l|l|l|l|l|}
\hline S. No & Years & Total Debt & Total Assets & Percentage \\
\hline $\mathbf{1}$ & $\mathbf{2 0 0 5}$ & $275,469,034$ & $298,776,797$ & $92.2 \%$ \\
\hline $\mathbf{2}$ & $\mathbf{2 0 0 6}$ & $301,263,929$ & $342,108,243$ & $88.06 \%$ \\
\hline $\mathbf{3}$ & $\mathbf{2 0 0 7}$ & $355,365,842$ & $410,485,517$ & $86.57 \%$ \\
\hline $\mathbf{4}$ & $\mathbf{2 0 0 8}$ & $385,179,850$ & $443,615,904$ & $86.83 \%$ \\
\hline $\mathbf{5}$ & $\mathbf{2 0 0 9}$ & $439,4837,14$ & $509,223,727$ & $86.30 \%$ \\
\hline
\end{tabular}

Total Debt to Total Assets: (NBP)

TABLE NO. 4.19

\begin{tabular}{|l|l|l|l|l|}
\hline S. No & Years & Total Debt & Total Assets & Percentage \\
\hline $\mathbf{1}$ & $\mathbf{2 0 0 5}$ & $503,378,402$ & $577,719,114$ & $87.13 \%$ \\
\hline $\mathbf{2}$ & $\mathbf{2 0 0 6}$ & $553,178,593$ & $635,132,711$ & $87.10 \%$ \\
\hline $\mathbf{3}$ & $\mathbf{2 0 0 7}$ & $645,855,939$ & $762,193,593$ & $84.74 \%$ \\
\hline $\mathbf{4}$ & $\mathbf{2 0 0 8}$ & $715,299,908$ & $817,758,326$ & $87.47 \%$ \\
\hline $\mathbf{5}$ & $\mathbf{2 0 0 9}$ & $824,676,384$ & $944,232,762$ & $87.34 \%$ \\
\hline
\end{tabular}

This ratio is similar to debt to equity capital in terms of funding sources that indicates the level of control that could be exercised by the providers of debt. Investors can exercise control over banks when repayments of principle and interest fall behind, by appointing receivers or receiver managers to take control of the assets. The total debt to total assets ratio of MCB for FY-2005-09 have decreased from 92.20\% to 86.3\% due to outstanding liabilities and interest bearing borrowings. On other hand NBP total debt to total assets 
have remain consistent for the FY-2005-09 because of the Government treasury repayment of outstanding liabilities and interest borrowings.

B.Debt-Equity Ratio

4) Total debt to equity capital: (MCB)

TABLE NO. 4.20

Total debt to equity capital: (NBP)

\begin{tabular}{|l|l|l|l|l|}
\hline S. No & Years & Total Debt & Total Equity & Percentage \\
\hline $\mathbf{1}$ & $\mathbf{2 0 0 5}$ & $275,469,034$ & $23,307,763$ & $1181.88 \%$ \\
\hline $\mathbf{2}$ & $\mathbf{2 0 0 6}$ & $301,263,929$ & $40,844,314$ & $737.59 \%$ \\
\hline $\mathbf{3}$ & $\mathbf{2 0 0 7}$ & $355,365,842$ & $55,119,675$ & $644.72 \%$ \\
\hline $\mathbf{4}$ & $\mathbf{2 0 0 8}$ & $385,179,850$ & $58,436,054$ & $659.15 \%$ \\
\hline $\mathbf{5}$ & $\mathbf{2 0 0 9}$ & $439,4837,14$ & $69,740,013$ & $630.17 \%$ \\
\hline
\end{tabular}

TABLE NO. 4.21

\begin{tabular}{|l|l|l|l|l|}
\hline $\begin{array}{l}\text { S } \\
\text { No }\end{array}$ & Years & Total Debt & Total Equity & Percentage \\
\hline $\mathbf{1}$ & $\mathbf{2 0 0 5}$ & $503,378,402$ & $74,340,712$ & $677.12 \%$ \\
\hline $\mathbf{2}$ & $\mathbf{2 0 0 6}$ & $553,178,593$ & $81,954,118$ & $674.99 \%$ \\
\hline $\mathbf{3}$ & $\mathbf{2 0 0 7}$ & $645,855,939$ & $11,633,7654$ & $555.16 \%$ \\
\hline $\mathbf{4}$ & $\mathbf{2 0 0 8}$ & $715,299,908$ & $102,459,218$ & $698.13 \%$ \\
\hline $\mathbf{5}$ & $\mathbf{2 0 0 9}$ & $824,676,384$ & $119,556,378$ & $689.78 \%$ \\
\hline
\end{tabular}

This ratio indcates the level of control that could be exercised by the providers of debt. Creditors can exercise control over banks when repayments of principle and interest fall behind, by appointing receivers or receiver managers to take control of the assets. The investments provided by the share holders during the FY-2005-09 of MCB are obtained higher from interest bearing borrowings and outstanding liabilities. The investments provided by the share holders during the FY-2005-09 of NBP are obtained higher from interest bearing borrowings and outstanding liabilities and the debt to equity capital had increased from $677.12 \%$ to $689.78 \%$.

\section{CONCLUSION AND RECOMMENDATION}

5.1 CONCLUSION:

A conclusion can be only be made if necessary information is provided about the financial analysis of both banks can be viewed. In the light of information about MCB provided in this report the work performance, efficiency, quality of customer services, market value and financial position of the MCB can be seen.

It's as clear as a day that MCB is totally changed after its privatization. It made a consistent growth. In spite the of political change in the country, change in the govt. policies external economic factor increase in inflation decrease in saving habits of the people, more reliance on foreign loans, the MCB has sustained its profitable position. After studying and a thorough financial analysis of MCB for last five years MCB growths in its assets has increased from Rs.298776797 (in thousands) to Rs.509223727 (in thousands) which is a positive sign of growth of bank. The liability of MCB had been decreased year by year during FY-200509 as compared to total assets. On the other hand total equity of the MCB bank for the FY-2005-09 had increase because of the increase in the net assets, and secondly the investor confidence on the banks increased which in turn increase the intangible assets of the bank. i.e., Good will in this competitive market. The return on equity (ROE) of the bank had shown fluctuation due to increase inflationary pressure and computerization of different branches and expansion of new branches with in and outside the country and increase in other expanses of the bank for the FY-2005-09.

The financial analysis of NBP for last five years had shown remarkable growths in its assets have increased from Rs.577719114 (in thousands) to Rs.944232762 (in thousands) which is a positive sign of growth of bank. The liability of NBP had been remained consistently year by year during FY-2005-09 as compared to total assets. On the other hand total equity of the NBP for the FY-2005-09 had also been remained consistent because of the working capital, and secondly the investor confidence on the bank because of government bank which enhanced because of the trust of the investor which in turn increase the intangible assets of the bank i.e. good will in this competitive market. The return on equity (ROE) of the bank had 
shown decreased because of not affective utilization of assets as compared to MCB bank and secondly control on their expanses because of adoption of new information technology and also renovation of branches within and outside the country that cause an increase in other expanses of the bank for the FY2005-09. The results based over the findings of the analysis of financial statements of both the banks shows that MCB had utilized their assets more efficiently and effectively as compared to NBP. The return on equity ratio of MCB Bank is much better then National bank of Pakistan for the FY-2005-09 which banks ability to produce earning \& therefore is an excellent indicator both of viability \& capability of banks management. A high return on equity reflects that banks acceptance of strong investment opportunities \& effective expense management.

\subsection{RECOMMENDATIONS:}

After a thorough analysis of financial statements of both the banks the recommendations which is to be given for the improvement of both the banks. The weakness of both banks must be converted into opportunity and make its strengths in order to compete into the global competitive markets. Proper survey and research should be conducted before the introduction of any new schemes and branches in order to first make a cost and benefit analysis as the main ingredient for the successful operation of business. Both of banks should take advantage from the prevailing new technology in the banking sector so as to earn profit from those niches which is ignored for many years and to provide best available services according to the needs and demands of the people in that niche. Loan procedure should not be cumbersome and should be made easy, so as to case the customers. Both the banks should adopt a lenient policy regarding advances of loans to the needy people and other deficit economic units which is the main source of revenue generation for the banks. Both the banks have liquidation problems the management of the banks must invest more in liquid assets like marketable security and market treasury bills to boost the trust of the depositors on bank. Both banks should also decrease their debt level in order to utilize the funds at the right time and at the right level to increase their net profits. Both banks should make best use of electronic and print media before launching any new schemes which benefits the people and the banks. The National bank of Pakistan should affectively utilize the technology and should computerization of different branches as well in short should invest more in information technology. There should be proper training (Up to date) for newly selected employees in order to make them more productive and to avoid over lapping of duties. The MCB bank should improve assets per employee ratio to increase the return of the assets per employee.

\section{REFERENCES}

[1] Ali, A. and Ansari, I. A. (2007). Financial sector reforms and soundness of banks operating in Pakistan, Journal of Management and Social Sciences, 3(2):63-69

[2] Barros, Ferreira, P.C, and Williams, J. (2007). Analyzing the determinants of performance of best and worst European banks." Journal of Banking and Finance, 31 (7):2189-2203.

[3] Berger, Allen N. (2005) Corporate governance and bank performance: A joint analysis of the static, selection, and dynamic effects of domestic, foreign, and state ownership Journal of Banking \& Finance, 29(8-9):2179-2221

[4] Boubakri, N. C, K. Fischer and O. Guedhami. (2005) Privatization and bank performance in developing countries, Journal of banking and finance, 29(8,9):2015-2041

[5] Emel, A. B. (2003). A credit scoring approach for the commercial banking sector Socio-Economic Planning Sciences, 37(2):103-123

[6] Hartvigsen, G. (1992), Limitations of knowledge-based systems for financial analysis in banking, Expert Systems with Applications, 4(1):19-32

[7] Hussain, S.A. Ijaz, (2008), International Banking Management, HIS Associate International Sharja, United Arab Emirates Edition $4^{\text {th }}$

[8] J. Iqbal, and Raza, G. (2009). Building global banks: A comparative analysis of European banks over time

[9] J. M. Shaikh, (2008). Hewlett-Packard Co. (HP) accounting for decision analysis: a case in International financial statement Analysis. International Journal of Managerial and financial Accounting, 1(1):75-96.

[10] John, H. Boyd, R. Levine, D. B. Smith (2001) The impact of inflation on financial sector performance Journal of Monetary Economics, 47(2):221-248

[11] Kitching, D. W. (1982), Rationalizing branch banking," Long Range Planning (15)1:53-62

[12] Kuljis, J, Robert D Macredie Information gathering problems in multinational banking, The Journal of Strategic Information Systems, 7(3):233-245 
[13] Laitinen, K. E. (2006). Financial statement analysis of a network of SMEs: towards measurement of network performance. International Journal of Networking and virtual Organizations, 3(3):258-282.

[14] Nabi, I, (1997). Outward orientation of the economy: A review of Pakistan's evolving trade and exchange rate policy Journal of Asian Economics, 8, (1):143-163

[15] Porta, L., Lopez, F. and A. Shliefer. (2002). Government ownership of banks. Journal of banking and Finance, 23 (6,7):2325-2311.

[16] Ravichandran, K. (2009). Financial statement analysis of Fundaram Clraton Limited. Working paper Series, King Saud University, S.A.

[17] Rehman, H. and S. Ahmad. (2008). An empirical analysis of the departments of banks selection in Pakistan. Pakistan Economic and Social Review, 46(2):147-160.

[18] Ruthenberg D. (1996), Cost economies and interest rate margins in a unified European banking market, Journal of Economics and Business, 48(3):231-249

[19] Sapienza, P. (2004). The effects of government ownership on bank lending” Journal of Financial Economics, 72(2):357-384

[20] Shahriar K and H. Tehranian (2010) The impact of state ownership on performance differences in privately-owned versus state-owned banks: An international comparison. The Journal of Financial Intermediation 19(1):74-79.

[21] Timo. S. and Teppo. (1994). A review of the theoretical and empirical basis of financial ratio analysis. The Finnish Journal of Business Economics, 4(94):426-448. 